УДК 94(3)

DOI 10.18413/2687-0967-2020-47-4-727-746

\title{
Принцевы острова в пенитенциарной системе Византийской империи
}

\author{
И.Ю. Ващева \\ Национальный исследовательский Нижегородский государственный \\ университет им. Н.И. Лобачевского, \\ Российская Федерация, 603950, Нижний Новгород, пр. Гагарина, 23 \\ E-mail: vasheva@mail.ru
}

\begin{abstract}
Аннотация. В статье рассматривается один из географических объектов Византии, расположенный недалеко от Константинополя и окутанный зловещим ореолом. При этом предпринимается попытка оценить место и роль получивших дурную известность Принцевых островов с точки зрения развития пенитенциарной системы Византии. В статье не только приводятся наиболее яркие примеры ссылки и заключения на Принцевых островах именитых и влиятельных особ, религиозных и политических деятелей Византии, но и предпринимается попытка гендерного, социально-статусного, количественного анализа заключенных, выявляются условия их содержания и цели заключения. Актуальность статьи определяется тем, что история Принцевых островов и их роль в Византийской истории изучены крайне мало и в то же время отличается наличием определенных стереотипов. Автор подвергает проверке и заново осмысливает ставшие уже стереотипными представления о роли Принцевых островов в византийской истории и приходит к выводу, что использование архипелага в качестве места заключения неугодных представителей царствующего дома носит вторичный характер. Определяющим же фактором заселения и освоения островов являлись идеальные условия для монастырского строительства. Изменение внутри- и внешнеполитической ситуации в VIII-IX вв. в сочетании с развитием законодательства и судебной системы в Византии приводят к тому, что довольно распространенной практикой наказания, а вернее, способом предотвращения потенциальной угрозы становится ссылка высокопоставленных противников и монастырское заключение. Это был удобный способ сохранить жизнь высокородным политическим соперникам и прямым оппонентам и в то же время устранить их надолго от участия в политической жизни. Принцевы острова в этом отношении как нельзя лучше подходили в качестве места (добровольного или принудительного) уединения, трудов и молитвенных занятий.
\end{abstract}

Ключевые слова: Принцевы острова, пенитенциарная система, тюрьмы Византии, места заключения, монастыри, «эпоха правового новаторства»

Для цитирования: Ващева И.Ю. 2020. Принцевы острова в пенитенциарной системе Византийской империи. Via in tempore. История. Политология, 47 (4): 727-746. DOI: 10.18413/2687-0967-2020-47-4-727-746.

\section{Prince's islands in the penitentiary system of the Byzantine Empire}

\author{
Irina Yu.Vashcheva \\ Lobachevsky State University of Nizhny Novgorod, \\ 23, Av. Gagarin, Nizhny Novgorod, 603950, Russia \\ E-mail: vasheva@mail.ru
}

\begin{abstract}
The article deals with one of the geographical objects of Byzantium, located near Constantinople and shrouded in an ominous halo. An attempt is made to evaluate the role of the infamous Prince Islands in terms of the development of the Byzantine penal system. The article not only provides the most striking examples of exile on the Islands of famous persons, religious and political figures of Byzantium, but also attempts to gender, social status, quantitative analysis of prisoners, reveals the
\end{abstract}


conditions of their detention and the purpose of imprisonment. The relevance of the article is determined by the fact that the history of the Prince Islands and their role in the Byzantine history has been studied very little and at the same time is characterized by certain stereotypes. The author checks some stereotyped ideas about the role of the Prince's Islands in Byzantine history and concludes that the use of the archipelago as a place of detention of undesirable representatives of the reigning house is secondary. The determining factor in the settlement and development of the Islands was the ideal conditions for monastic construction. Changes in the domestic and foreign political situation in the VIII-IX centuries in combination with the development of the judicial system in Byzantium brings an appearance of quite common practice to punish, or rather to prevent a potential threat, the exile of high-ranking opponents and monastic imprisonment. It was a convenient way to save the lives of high-born political rivals and direct opponents and at the same time remove them from political life for a long time (Refs 50).

Keywords: Prince's Islands, penitentiary system, Byzantine prisons, places of detention, monasteries, «the age of legal innovation».

For citation: Vashcheva I.Yu. 2020. Prince's islands in the penitentiary system of the Byzantine Empire. Via in tempore. History and political science, 47 (4): 727-746 (in Russian). DOI: 10.18413/2687-09672020-47-4-727-746.

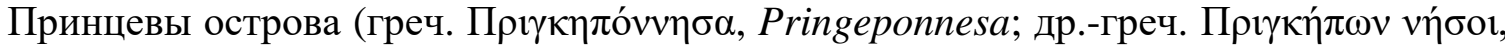
Pringēpōn nēsoi) - это архипелаг, состоящий из 9 островов и расположенный в Мраморном море недалеко от Константинополя (совр. Стамбула). Происхождение названия островов часто связывают с тем, что во времена Византийской империи на них ссылали опальную знать - родственников императора, видных государственных деятелей и прочих возмутителей спокойствия, осмелившихся покуситься на престол ${ }^{26}$. Сегодня Принцевы острова являются одним из самых экологически чистых, живописных и престижных мест региона, но славятся они не только своими красивейшими видами, но и богатой историей. Правда, эта история окутана специфическим ореолом. Как пишет С.А. Иванов, «на каждом из островов кого-то мучили, лишали зрения и держали в оковах» [Иванов, 2013, с. 579]. И действительно, примеров тому немало.

Однако в задачи данной статьи не входит ни перечисление жертв и узников Принцевых островов, ни пересказ леденящих душу примеров; более важными и продуктивными, на наш взгляд, являются выявление различных аспектов жизни этого архипелага, анализ действительной роли Принцевых островов в Византийской истории, установление времени и причин начала использования архипелага в качестве места ссылки и заключения высокопоставленных особ.

Источниковая база истории Принцевых островов весьма неоднородна и специфична. Практически все материальные свидетельства византийской эпохи на крупных островах архипелага уничтожены современным строительством. Маленькие необитаемые островки лучше сохранили свидетельства прежних эпох. Однако целенаправленного, систематического археологического исследования островов, насколько нам известно, не проводилось. Более того, на островах расположены некоторые объекты, вход на территорию которых категорически воспрещен.

Письменные источники более доступны и разнообразны, однако содержащаяся в них информация весьма небогата и однотипна. В исторических произведениях [Оболенский и др., 1860; Липшиц, 1950; Чичуров, 1980; Любарский, 2009], как правило, можно найти лишь упоминания о том, что такой-то и такой-то был сослан и закончил свои дни на

${ }^{26}$ По другой версии, восходящей к Кедрину, Принцевы острова получили свое название в VIII в., когда император Юстин II построил здесь роскошный дворец для своего наследника. См., например: [Lawler, 2004, p. 240]. Ср. Феофан 563: «В этом году царь Юстин начал строить другой дворец в подгородной даче, которою владел до своего воцарения, равно на острове Принцевом устроил другой загородный дворец - церковь святых бессребреников, в урочище Дария». 
одном из Принцевых островов. Более живую и развернутую картину дают агиографические сочинения - жития того или иного мученика или пострадавшего от гонений церковного деятеля, в которых в красках рассказывается о мучениях, которым те подвергались, и условиях, в которых они содержались на острове, хотя, возможно, многие сведения значительно приукрашены.

Что касается степени изученности истории Принцевых островов и их роли в пенитенциарной системе Византийской империи, то можно констатировать наличие в научной литературе двух-трех стереотипных утверждений, чем собственно изучение данной проблематики и исчерпывается. Принцевы острова как географический объект рассматриваются, пожалуй, только в путеводителях по окрестностям Стамбула, где неизменно отмечается их зловещая слава [Филиппов, 1915; Коркмас, Скоковская, 1919; Pokock, 1745; Freely, 2007; Sartorius, 2011]. Выгодно выделяется на этом фоне работа С.А. Иванова, в которой Принцевым островам и связанным с ними известным людям посвящена целая глава (19 стр.) [Иванов, 2013, с. 579-597] с цитатами из оригинальных источников. Однако в качестве объекта исторического исследования и, в частности, в контексте «истории наказаний» Принцевы острова никогда ранее не рассматривались.

История византийского права, юридических институтов и практик в империи привлекали внимание ученых еще с XIX в. [Суворов, 1876; Азаревич, 1877; Фойницкий, 1889; Dagron, 1994; Morris, Rothman, 1998; Humphreys, 2015; Chitwood, 2017; Stolte, 2018, p. 229-248]. Но и в этих исследованиях Принцевы острова если и упоминаются, то очень бегло и кратко. История тюрем и пенитенциарных учреждений, как и практика наказаний в Византии, изучена довольно слабо. Можно сказать, появляются только еще первые работы в этой области [Кущ, 2014, с. 82-95; Hillner, 2007, p. 205-237; Hillner, 2011, p. 39-56; Hillner, 2013; Hillner, 2015; Chitwood, 2017]. В изданиях по истории Византии Принцевы острова если и упоминаются, то крайне редко и мимоходом.

Первые упоминания о ссылках высокопоставленных особ на острова данного архипелага относятся к 565 г. В частности, сообщается, что патриарх Евтихий провел 3 недели в заключении на острове Принкипо [Иванов, 2013, с. 590; Allen, 1980, p. 10-11; Whitbey, 1987, p. 297-308; Cameron, 1988, p. 225-247; Laga, 1992].

В 635 г. «поверив доносам, император Ираклий приказал сослать сюда своего внебрачного сына Аталариха», отрубив ему нос и руку по обвинению в участии в заговоре [Липшиц, 1950].

Следующее подобное упоминание в источниках появляется, пожалуй, лишь в 60-е гг. VIII в., когда naтриарх Константин (754-766) в связи с заговором «19 вельмож» будет низложен и отправлен в ссылку на Принкипо («Княжий остров»), а позднее возвращен в столицу, чтобы подвергнуться публичному осмеянию, осуждению и жестокой казни от императора Константина V [Afinogenov, 2010, p. 207-214].

Острова сыграли свою роль в судьбе женщин императорского дома на рубеже VIII-IX вв. В январе 795 г. Константин VI, сын императрицы Ирины, насильно заставил свою первую жену Марию (Амнийскую) принять монашество, и вместе с дочерьми Ириной и Ефосиньей Мария была сослана в монастырь на одном из Принцевых островов, где она и скончалась монахиней в 821 г. Одна из дочерей Марии Евфросиния (правнучка св. Филарета Милостивого и внучка императрицы Ирины) ок. 823 г. будет вызвана из монастыря и станет женой императора Михаила Травла II. История эта наделала много шума в столице (Cont. Theoph. II. 24) [Любарский, 2009]. Для нас же она важна тем, что ссылка женщин императорского дома на Принцевы острова в IX в. становится весьма распространенной практикой. Сама императрица Ирина не избежала этой участи. В 802 г. Никифор, захватив власть, «получивши желаемое, тотчас послал ее на остров Принцип, в обитель, которую она устроила». Спустя некоторое время, опасаясь волнений, Никифор отправил ее на о. Лесбос, где она через полгода и скончалась. Тело же ее было возвращено на о. Принкипо в построенную ей обитель (Theoph. а. 6295 / 795) [Оболенский и др., 1860]. Вероятно, новый импе- 
ратор Никифор, захвативший власть путем заговора, не считал Принцевы острова достаточно удаленным и надежным местом для содержания ссыльной императрицы.

Примерно в это же время неудавшийся претендент на власть Вардан, желая избежать наказания, добровольно приняв монашеский постриг, с согласия императора удалился на о. Проти 27.

С 809 по 811 гг. провел в заключении на Принцевых островах и Феодор Cmyдum ${ }^{28}$ со своими сподвижниками (преп. Феодор был отправлен в монастырь на острове Халки, архиепископ Иосиф - на Проти, авва Платон - на Оксию) (Theod. Stud. Orat. Funer. In Platon) [Митр. Владимир, 2011, с. 242; Migne, 1857, col. 803-849]. Здесь преп. Феодор по обыкновению вел обширную переписку со своими учениками и почитателями, которых поощрял на подвиг, утверждал в истине, восхвалял за исповедничество, убеждал не принимать антицерковного постановления Константинопольского собора 809 г. Он стремился даже составить коалицию против императора, пытаясь заинтересовать в византийском противомихианском движении православный Восток и Рим. Находясь в заключении, писал письма к Римскому папе Льву, однако папа Лев ответил на все ходатайства преп. Феодора о содействии лишь моральным сочувствием [Преображенский, 1896; Гроссу, 1907; Доброклонский, 1913-1914; Соколов, 2005]. Освобожден же он был в 811 г. после прихода к власти нового императора.

C 813 по 844 гг. на Платии жил в заключении свергнутый Львом V Михаил I с сыновьями Евстратием и Никитой (будущий naтриарх Игнатий) ${ }^{29}$. Сам Лев V был убит в 820 г. Михаилом Аморийским, который унаследовал трон как Михаил II. Михаил затем

27 «В июле месяце, 19 числа; в четвертый день недели, в 1-м часу, Варданес патриций и военачальник восточный, по прозванью Турк, провозглашен был царем заграничными легионами; хотя он долго отказывался, но не мог уклониться от них, пришел к Хрисополису и, ходивши около его 8 дней, не был принят жителями города и возвратился в Малагины. Но, убоявшись Бога и приняв на совесть, чтоб за него не произошло убийство христиан, писал к Никифору и, получивши от него письменное честное слово $u$ собственноручно подписанное, к которому подписались святейший патриарх Тарасий и все патриции, что он будет соблюден без вреда и наказания, равно как и все, державшие его сторону, 8 числа сентября, в полночь, тайно ушел он от войска, прибыл в Кий вифинский, в обитель Ираклия и, нашедши здесь присланную от царя ладью, тогда же остригся, надел монашеское платье и на ладье отправился на остров, называемый Проти, на котором он устроил монастырь, надеясь, что лютый Никифор уважит данное им страшное слово и ни в чем не будет вредить ему» (Theoph. а. 6295 / 795).

${ }^{28}$ Находясь на Халках, Феодор написал несколько писем, богословских трактатов и стихотворений, одно из которых было с любовью адресовано монашеской келье, в которой он был заключен. Феодор не называет имени монастыря, но другие свидетельства, по-видимому, указывают на то, что это была Святая Троица. В письмах Феодора говорится, что после убийства Льва V в 820 г. его вдова, императрица Феодора, и ее дочери были сосланы в монастырь на Халках новым императором Михаилом II. Феодор и другие жители Святой Троицы были затем выселены, чтобы освободить место для императрицы и ее дочерей. Таким образом, на Халках, по-видимому, было еще одно монастырское учреждение, где могли найти приют перемещенные монахи, и, возможно, это был монастырь Святого Иоанна Крестителя.

29 «А когда Лев вступил в город, Михаил обрезал вместе с женой и детьми волосы и отправился в божье святилище, именуемое Фаросом..., чтобы вымолить благосклонность нового царя. А тот решил, что негоже отрывать от бога и лишать жизни Михаила, и потому отправил его изгнанником на остров Плат, велел жить там незаметно и положил ежегодные денежные выдачи. Рассказывают, что там он принял монашество, получил имя Афанасия и прожил еще тридцать два года. При нем находились его сын Евстратий, по приказу Льва постриженный и оскопленный 20 лет от роду, и Никита, который прежде еще мальчиком командовал иканатами (он стремился дружить с воинами и теми, кто проводил жизнь под открытым небом и опытен был во многих делах), а тогда тоже постригся, был прозван Игнатием, проводил свои дни с отцом и пристрастился к иноческой жизни. А вот супругу его Лев отнял, отделил и переселил в монастырь Прокопии, хотя Михаил горячо просил этого не делать. Михаил ушел из жизни 11 января 6032 г., оставил свой прах на том же острове и был похоронен на правой половине церкви. Евстратий же после смерти отца прожил еще 5 лет, усоп 15 января 6037 г. и упокоен на левой стороне церкви. Игнатий же, прежде именовавшийся Никитой, сподобившись сана константинопольского епископа, много позже предал погребению его святое тело в монастыре Сатира, который сам незадолго до того возвел от основания» (Сont. Theoph. I. 10). 
сослал вдову Льва, Феодосию, и ее четырех детей в монастырь Панагии, или Святой Девы, на о. Проти, где были похоронены останки свергнутого императора.

Примерно в это же время (с 823 по 829 гг.) на Антигоне томился в заключении предшественник Игнатия - константинопольский патриарх Мефодий. Самые яркие и драматичные страницы истории Принцевых островов связаны, пожалуй, с пребыванием здесь именно этих двух опальных патриархов - патриарха Константинопольского Мефодия (843-847), а затем его преемника - патриарха Игнатия (847-858, 867-877).

Житийные тексты в красках повествуют о том, что будущий патриарх Мефодий просидел в заключении в подземной тюрьме с конца 823 по весну 829 г.: «Император [Михаил II Травл] велел бичевать блаженного бычьими жилами по лицу, а потом заточил его в тесной могиле, имевшей узкое отверстие, через которое ему спускали скудное продовольствие. Вместе с ним в подземелье были заточены два преступника, а снаружи приставлена неусыпная стража. Прошло немного времени, и эти двое умерли, не снеся зловония и темени подземного склепа, а также нестерпимой прожорливости вшей. Выжил один лишь этот благородный и сверхъестественно выносливый муж - Мефодий. Кто бы еще вынес полчища мышей, которые завелись в мертвых телах и докучали погребенному заживо Божию человеку. Этот упрямец потерял все волосы с головы, проведя в ужасном узилище пять лет». Правда, по другой версии, умер лишь один из разбойников, а у Мефодия хватило душевных сил, чтобы обратить второго к покаянию [Иванов, 2013, с. 583]. Из данного текста не ясно, за что патриарх, известный своей праведной жизнью, и двое преступников заслужили одинаково суровое наказание. В юридических памятниках той эпохи также не предписывается строгое тюремное заключение в качестве наказания за какиелибо определенные преступления. Поэтому вызывает сомнение, что патриарх и обычные преступники могли оказаться в одной темнице.

Впрочем, вполне возможно, что автор жития использует здесь стандартные клише, возможно, несколько преувеличивает ужасы заточения, дабы показать мученический венец подвижника. Другие источники рисуют условия заключения Мефодия несколько в ином свете. Сообщается, в частности, что его соратники в борьбе за иконы Феодор и Феофан «передали ему письмо через одного верного человека, рыбака, который прислуживал святому Мефодию в его нехитрых надобностях. По причине темноты его склепа он каждую субботу приносил ему лампадного масла на одну монету, и этого хватало на то, чтобы светить узникам в течение недели. Однажды рыбак заболел и не принес свою обычную порцию масла, но по молитве святого Бог восполнил недостачу». Во всяком случае, известно, что святые иноки-исповедники Феодор и Феофан Начертанные послали святому Мефодию приветствие в стихах, и узник, находясь в подземелье («запертый в гробовой пещере»), также ответил стихотворным приветствием [Димитрий Ростовский, 1903-1911, с. 781-782] (!). После многих лет заключения на Антигоне в регентство императрицы Феодоры Мефодий был освобожден и стал патриархом. Как сообщает Продолжатель Феофана, «тот, кто многочисленными трудами и подвигами в неприкосновенности соблюл добродетель, кто из-за длительного заключения в гнилости и грязи лишился волос, но от бога и царицы Феодоры обрел управление и власть над церковью. А был это великий Мефодий - неодолимый ревнитель церкви» (Cont. Theoph. IV. 3).

Таким образом, ссылка и заточение в склепе на островах не помешали ему не только выжить, но и поддерживать отношения со своими соратниками, писать стихотворные послания и даже вернуться к активной политической деятельности.

Особую роль сыграли Принцевы острова и в судьбе другого Константинопольского nатриарха Игнатия (797-877). Будучи сыном византийского императора Михаила I Рангаве, он еще ребенком оказался заключен в монастырь, после того как его отец в 813 г. был свергнут с престола. Он был оскоплен и в 14 лет стал монахом. Здесь он развернул бурную деятельность, «Принцевы острова Платия, Ятрос и Теревинф были обжиты его попечением и наполнились храмами Божьими и обителями монахов» [Иванов, 2013, 
c. 593]. Им было основано три монастыря на Принцевых островах [Pargone, 1902]. Пробыв в монастырях 33 года, 4 июля 847 г. святой императрицей Феодорой он был возведен на престол Константинопольского патриарха [Beck, 1979, S. 96] как стойкий борец против иконоборчества. Придерживаясь консервативных взглядов, Игнатий завоевал популярность у народа, но навлек на себя нерасположение высшего духовенства. В 856 г. он вступил в открытый конфликт с Вардой, регентом малолетнего императора Михаила III, открыто осудив его грехи и отлучив от причастия. Патриарх увещевал Варду оставить греховную жизнь и смело обличал его беззакония. По приказу Варды святителя мучили 15 дней, заставляя отречься от сана, но не добились ничего (Cont. Theoph. IV. 30-31). Когда в 857 г. Варда хотел заставить святителя постричь в монахини святую царицу Феодору, мать императора, чтобы удалить ее от управления государством, то святой патриарх Игнатий не только не согласился на это, но даже всенародно отлучил Варду от причастия. Не посмев напрямую свергнуть патриарха, Варда свалил на святителя вину за мелкий бунт и, убедив императора в правдивости обвинения, сослал Игнатия на остров Теревинф, один из Принцевых островов. Императрица Феодора тогда же была заключена своим сыном Михаилом III в монастырь на Неандросе, самом маленьком из Принцевых островов. На патриарший престол был поставлен светский чиновник Фотий, человек безусловно яркий и выдающийся, но оказавшийся у власти стремительно и в нарушение всех правил поставления патриарха. Низложенный патриарх Игнатий из ссылки обращается за помощью к Римскому папе (!), что положило начало «Фотианской схизме». Здесь опальный патриарх развернул бурную деятельность и занялся восстановлением монастырей и часовен, пострадавших от набегов россов в 860 г. ${ }^{30}$ В 867 г., после убийства императора Михаила III и утверждения у власти Василия Македонянина, Игнатий был возвращен из ссылки и восстановлен в сане патриарха, в коем и оставался вплоть до своей кончины в 877 г.

Примечательно, что сосланные патриархи - люди в высшей степени достойные, не совершившие никаких преступлений (наказывать их было не за что), но своей принципиальной позицией мешавшие проведению императорской политики. Оба патриарха описываются как герои, претерпевшие мученичества за веру. Правда, основные мучения патриapx Игнатий, например, претерпел в столице, а не на островах. Судя по всему, ссылка и заключение, описываемые в исторических источниках одной строчкой, не вызвали столь бурной реакции у современников. Агиография дает более эмоциональное описание их мученического пути, но вместе с тем и более тенденциозна.

В следующий раз Принцевы острова упоминаются в связи с драматичными историями из жизни византийских правителей уже в X в. Так, 17 декабря 944 г. на остров Проти был привезен Роман Лакапин, свергнутый собственными сыновьями. А всего через несколько дней, 27 декабря, сыновья Романа, сами ставшие жертвой заговора и дворцового переворота, в свою очередь свергнутые Константином Багрянородным, последовали за отцом. Драматичнейшую сцену описал современник Лиутпранд: «Когда Роман, отец их, услышал о том, что они прибыли, он вышел за ворота монастыря им навстречу и с радостным лицом сказал: «Какая, - говорит, - радость, что ваши величества решили навестить здесь наше ничтожество. Полагаю, что именно сыновняя любовь, изгнавшая меня из дворца, не позволила вам долго там оставаться. Как хорошо, что вы отправили меня вперед. Ведь братия не знала бы, как принять императоров, если бы не имела меня, издавна поднаторевшего в имперских церемониях. Готов уже отвар из воды, сладкие бобы и молодой чеснок». Пока Роман насмехался над ними, Стефан и Константин стояли пристыженные, устремив глаза в землю» [цит. по: Иванов, 2013, с. 581].

${ }^{30} \mathrm{O}$ богоугодной деятельности Игнатия и реакции властей на его «самоуправство» в подробностях рассказывает «Житие патриарха Игнатия» Никиты Пафлагона [Migne, 1862, col. 487-575]. Об этом произведении см. также [Васильевский, 1899; Smithies, 1988]. 
Как видно из данных описаний, Роман и другие неудавшиеся императоры были отправлены на Принцевы острова в монастырь. Никакого строгого тюремного заключения, очевидно, тут не предполагалось. Роман жил вместе с братией, трудился вместе с монахами, вместе с ними и принимал трапезу. Очевидно, разрешались посещения, допускалось общение, так что бывший император не должен был провести оставшуюся жизнь в полном уединении и одиночестве, и уж тем более подвергаться каком-либо физическому насилию.

В 969-970 гг. на остров Проти была сослана и знаменитая Феофано (Leo Diac. VI. 4) [Попов, 1820], убившая в декабре 969 г. своего мужа императора Никифора Фоку и посадившая на престол Иоанна Цимисхия. Ей удалось вернуться в Константинополь, где она пыталась найти убежище в церкви Св. Софии. Однако Иоанн Цимисхий остался непреклонен. Он послал в Св. Софию своего верного евнуха Василия Нофа, равнодушного к женским чарам, и тот «выволок ее, причем она крепко ругалась на императора и на Василия, обзывая его скифом и варваром, и била кулаками по щекам» [Иванов, 2013, с. 581]. На основании этих скудных данных можно заключить, что Феофано, очевидно, не содержалась под стражей, если смогла подготовить побег и организовать свое возвращение в столицу, хотя естественные преграды (монастырские стены и море) должны были удержать ее на безопасном расстоянии от столицы.

В 1042 г. на Принкипо была сослана императрица Зоя (Mich. Psel. 5. XXI-XXIII) [Любарский и др., 2003]. В монастыре на Принкипо жили в заточении также Анна Далассина ${ }^{31}$, Ирина Дукена и Мария Аланская.

Интересную информацию о заключении Марии Аланской дает письмо архиепископа Фефилакта Охридского [Gautier, 1986; Иванов, 2013, с. 591], которому опальная императрица некогда покровительствовала, но которую он не навестил, проплывая мимо на корабле. Он пишет: «Пусть знает твоя царственность, что я множество раз и подолгу приставал к матросам, чтобы они повернули руль и направили паруса на островок Прикипо, где счастливо пребывает твое величество. Но для них мои грозные вопли не долетали, думаю, из-за того, что уши им забивал еще более грозный вой северного ветра». Данная ситуация весьма любопытна в том отношении, что архиепископ вынужден оправдываться за то, что он не навестил императрицу в ссылке, т. е. он не только мог, но и должен был ее навестить. И помешали ему это сделать не страх наказания от грозного императора, но «грозный северный ветер». И в целом он не стесняется писать, что императрица «счастливо пребывает» на одном из островов. Очевидно, что условия содержания царственной особы на острове были не такими уж суровыми и вполне соответствовали ее статусу.

В 1072 г. на Принцевых островах в муках закончил свои дни свергнутый и ослепленный император Роман Диоген (1067-1071). Это было, пожалуй, последнее крупное и столь драматичное событие, связанное с Принцевыми островами ${ }^{32}$.

Михаил VII Дука (1071-1078) был заключен в монастырь, после того как он был низложен и ослеплен в 1078 г., и оставался там до своей смерти в 1090 г.

C начала XII в. Принцевы острова почти не упоминаются в качестве места ссылки и заключения.

Итак, история островов оказалась связана с жизнью многих исключительно ярких, неординарных, уникальных личностей, оставивших свой след в истории Византийской империи. При этом можно сделать определенные наблюдения.

Bo-nервых, хронологический анализ показывает, что наибольшей популярностью в качестве места ссылки острова пользовались в IX-XI вв.

До начала IX в. наиболее частым местом ссылки выступали о-ва Эгейского моря, особенно о-в Родос (куда были сосланы, например, вдова и дети императора Ираклия),

${ }^{31}$ Подробнее об Анне Далассине: [Диль, 1994, с. 96-110].

32 По некоторым данным, в 1073 г. на Оксию бежал и искал убежища неудачливый узурпатор Иоанн Дука, однако данное событие не имело такого резонанса и византийскими источниками осталось практически незамеченным. 
Фракия (Максим Исповедник), Херсонес Таврический (папа римский Мартин, Юстиниан II и др.), Грузия (Максим Исповедник), Абхазия (Иоанн Златоуст) и др. Но в VII в. активизируются арабы, которые начиная с 654 г. начинают захватывать острова Родос, Кос, Крит и др., что надолго выводит острова из состава византийских владений.

Другим весьма удобным местом для удаления опасных политических противников в ранневизантийский период выступал г. Херсонес в Северном Причерноморье. В конце V - начале VI в. Херсонес (Херсон) вошел в состав Восточно-Римской империи и стал северным форпостом Византии, через который осуществлялся контроль за передвижением варварских племен, представлявших потенциальную угрозу безопасности империи. Византийцы постоянно держали эту стратегически важную крепость под политическим, экономическим и идеологическим контролем и, учитывая отдаленность Херсона, использовали его как место ссылки оппозиционеров, неугодных церковных и политических деятелей. В разное время сюда были сосланы монофизит Тимофей Элур (60-е гг. V в.), римский папа Мартин, Феодор и Евперий (655 г.), низверженный император Юстиниан II Ринотмет (695-705 гг.), его соперник Филиппик Вардан, брат императора Льва Хазара - кесарь Никифор (776 г.), и даже в IX в. монахи-иконопочитатели - сподвижники Феодора Студита: Иоанн Психиат и Иосиф Песнописец.

Таким образом, острова Эгейского моря и весьма удаленное от центра Северное Причерноморье активно использовались византийскими императорами в качестве места ссылок политических противников в период до середины VII в., довольно редко - в VIII в. C IX в. мы практически не встречаем упоминаний о ссылках политических или религиозных деятелей в эти регионы.

Так, первой ключевой точкой в развитии пенитенциарной системы Византии служит рубеж VIII - IX вв. Вторым поворотным моментом служит конец XI в. Именно на эти три столетия (с начала IX до начала XII в.) приходится пик активной жизни Принцевых островов в данном качестве.

Очевидно, что важнейшим фактором, определившим подобную динамику и объясняющим появление тенденции к активному использованию Принцевых островов, стали внешнеполитические изменения в регионе в период VIII-IX вв., когда Византийская империя сталкивается с серией внешнеполитических вызовов. В начале VIII в. в Византии сложилась чрезвычайно сложная внутри- и внешнеполитическая обстановка. Внутренняя смута и рост местного сепаратизма соседствовали с мощным наступлением арабов, угрозой со стороны лангобардов, болгар и славян, потерей целого ряда провинций государства. К 700 г. территория империи уменьшилась в четыре раза (!) по сравнению с периодом правления знаменитого императора Юстиниана I (сер. VI в.). По словам выдающегося русского византиниста А.А. Васильева, «в момент восшествия Льва на престол Византия переживала один из критических периодов своей истории. Так, в 728 г. лангобарды овладели Равенной и начали устанавливать свое господство на севере Италии, лишь формально являвшейся в то время провинцией Византии. В руках арабов оказались недавно столь успешно отвоеванные у персов Сирия, Палестина, Египет, а также часть Малой Азии и византийские провинции в Северной Африке [Васильев, 1998a, с. 318].

В конце VIII - 1-й пол. IX в. международное положение империи определялось, с одной стороны, ростом могущества Франкской державы с коронацией Карла Великого императорской короной в 800 г., претендующей на имперский статус, и усилением внешнеполитического давления со стороны Багдадского халифата, с другой. Кроме того, серьезную опасность представляла Болгария. Император Никифор I попытался разбить хана Крума, вторгшись в Болгарию, взял столицу болгар Плиску, но на обратном пути потерпел сокрушительное поражение и погиб, а болгары, вновь захватив Адрианополь и остальные крепости на подступах, появились у стен Константинополя в 813 г. С 1-й пол. IX в. важным фактором византийской внешней политики становятся взаимоотношения с зарождающимся на севере от империи гос- 
ударством русов. Плюс ко всему, в 821-823 годах произошла одна из самых крупных гражданских войн в Византийской империи - восстание Фомы Славянина.

Набеги арабов на территории Византийской империи, борьба со славянами на Балканах, вероятно, делают традиционные направления ссылок оппозиционеров весьма ненадежными. Подтверждением тому стало, например, появление у стен Константинополя в 705 г. низложенного и сосланного императора Юстиниана II вместе с болгарским войском [Дашков, 1997, с. 116-121; Васильев, 1998b, с. 266-315; Успенский, 2005, с. 450; Stratos, 1980]. Вполне вероятно, что в новых условиях требовалось не просто удаленное от столицы место, но место труднодоступное, отделенное естественными преградами от крупных византийских центров и от границ, где политические противники могли бы вступить в контакт с врагами Империи, но достаточно близкое к Константинополю, чтобы можно было держать сосланных противников под постоянным контролем. Острова Эгейского моря и Северное Причерноморье в новых условиях не отвечали таким требованиям. Принцевы острова же, находящиеся в нескольких километрах от Константинополя, и в то же время отрезанные от внешнего мира морем ${ }^{33}$, мало населенные (почти необитаемые), становятся идеальным местом для содержания опасных противников. Без посторонней помощи и хотя бы лодки вернуться в Константинополь в условиях IX - X вв. было практически невозможно.

Bo-вторых, простейший количественный анализ особ, сосланных на острова архипелага, говорит о том, что в числе заключенных здесь побывало не только порядка двух десятков светских особ, преимущественно неудачных претендентов на императорский престол, потенциальных претендентов на власть или же опальных представителей царствующего дома, но и немало представителей церкви. При этом некоторые деятели церкви удалялись на острова добровольно, не в качестве заключенных, но в поисках уединения и монашеского подвига. С начала XII в. здесь поселяются, пожалуй, только бывшие патриархи. Так, на Оксию был сослан патриарх Михаил Куркуас, занимавший патриарший престол в 1143-1146 гг. Сложив с себя полномочия, он добровольно вернулся на Оксию, где когда-то принял постриг. По словам Никиты Хониата, «Михаил оксийский... добровольно отказавшись от верховной кафедры, возвратился на остров Оксию где он издетства проводил подвижническую безмятежную жизнь, и, простершись на земле, при входе в преддверие храма, отдал выю свою на попрание всякому входящему монаху, сознаваясь, что он напрасно оставлял давнишнее и любезное ему спокойствие и без всякой пользы восходил на верховный престол» (Nic. Chon. Hist. Man. Comn. II. 3) [Долоцкий, 1860-1862]. В 1183 г. патриарх Феодосий ушел в основанный им монастырь на Теревинфе. В этих случаях речь идет не столько о ссылках неугодных оппозиционеров и насильственном заключении под стражу, сколько о добровольном пребывании в монастыре и подвижнической жизни. Принцевы острова с их нетронутой природой, удаленные от суеты Константинополя и крупных городов, представляли собой идеальное место для уединенной жизни, трудов и молитвенных занятий.

$B$-mpeтьих, гендерный анализ показывает, что среди заключенных было много женщин. Нам известно не менее 10 представительниц царского рода, окончивших свою жизнь в монастырях Принцевых островов. Причем большая часть из них пребывала в монастырях архипелага не в качестве ссыльных или заключенных, а как благочестивые вдовы, добровольно (или не очень) принявшие постриг после смерти своих мужей.

$B$ целом же устойчивое представление о зловещей роли Принцевых островов представляется сильно преувеличенным. В большинстве случаев речь идет не о строгом тюремном заключении (наличие здесь тюрем или других строгих пенитенциарных учреждений, видимо, даже не предполагается), а о монастырском заключении.

${ }^{33}$ Интересно, что из 60 византийских монастырей, уставы которых дошли до нас, 40 (включая константинопольские и афонские) располагались на островах или на побережье [Thomas, Hero, 2000, p. 20]. 
Условия содержания были весьма сносными. Некоторые из монарших особ (женщины) даже получали содержание из императорской казны. Другие после многих лет заключения смогли вернуться к активной политической жизни. Да и во время самого заключения, как показывают источники, они вели активную переписку со своими сторонниками и даже с Римскими папами. Вероятно, использование островов архипелага византийскими императорами как места заключения для политических оппонентов вторично. Главным же фактором явилась активная монастырская застройка островов.

Надо сказать, что острова, расположенные в нескольких километрах от столицы и в то же время даже в пространственном отношении отрезанные от мира, представляли собой практически идеальное место для монастырского строительства. Само наличие водной преграды уже символически маркирует «уход от мира». Острова в то время были мало обитаемы, что также давало возможность вдали от шума городов, от мирской суеты сосредоточенно молиться и размышлять о вечном. Поэтому довольно рано, по крайней мере, с VI в., на островах начинают появляться монастыри. К XII в. на всех крупных островах архипелага было уже по 2-3 монастыря, на мелких - по одному. Единственный остров, на котором, видимо, не было монастыря и своей специфической истории, - это маленький остров Пита.

Известно, что император Юстин II основал в 569 г. женский монастырь на Принкипо, впоследствии перестроенный и расширенный императрицей Ириной. Помимо него большой славой пользовался монастырь св. Георгия, в котором излечивали бесноватых, а также монастырь св. Николая. На Проти сохранились остатки монастыря, основанного неудачным претендентом на престол Варданом, и Преображенского монастыря, заложенного в XI в. Романом IV. На Антигоне был еще один Преображенский монастырь, по преданию, основанный Василием I. По источникам он прослеживается с X в. А последние дошедшие до нас сведения об этом монастыре относятся к XII в., в связи с вторжением во Фракию болгарского войска и пленения множества паломников во время праздника св. Георгия в окрестностях Цурула из-за корыстолюбия некоего монаха Антигонова монастыря [Иванов, 2013, с. 581]. На о. Халки существовал монастырь св. Троицы, в котором, очевидно, отбывал ссылку Феодор Студит. Он же сообщает, что в 820 г., когда вдову императора Льва V с сыном отправили на о. Халки, монахов из Троицкого монастыря вместе с игуменом «изгнали из обители». Возможно, для нужд шатающихся монахов был основан другой - Верхний Богородичный монастырь [Иванов, 2013, с. 588-589]. Здесь же находится единственный сохранившийся во всем архипелаге византийский памятник - Нижний Богородичный монастырь, и в нем - церковь Марии Камариотиссы [Mathews, Mango, 1973, p. 115-132] XI-XII вв. На Оксии известен монастырь, из которого вышло несколько патриархов Константинополя. На Теревинфе был монастырь, основанный патриархом Феодосием, и еще один, основанный патриархом Игнатием. На Платии в начале VII в. был основан монастырь 40 мучеников. Усилиями патриарха Игнатия «были обжиты три дальних острова» (Платия ${ }^{34}$, Ятрос (Неандрос) и Теревинф). Хотя точное количество монастырей, основанных в византийские времена на островах архипелага, неизвестно, письменные источники называют не менее 14 обителей, существовавших с VI по XIII вв. на этой небольшой территории.

Особенно бурно разворачивается монастырское строительство по всей Византийской империи, и в том числе на островах, со второй половины IX в., с восстановления иконопочитания. Собор 843 г. вынужден был даже принять ряд мер, ограничивающих монастырское строительство [Соколов, 1894a; Соколов, 1894b].

Кроме того, важно, что не только Принцевы острова становились местом пристанища политиков, удаленных со сцены. Намного опережал их в этом отношении Студийский монастырь. «Лица, удалявшиеся или удаляемые со сцены, если до тех пор они занимали высокое общественное положение или обладали большим богатством, поступали обыкновенно

${ }^{34}$ В 1307 г. Константин Мелитиниот похоронен на Плати, а в XIV веке он уже был практически необитаем. 
в знаменитый Студийский монастырь, находившийся в самом Константинополе. Цари считали этот монастырь самым приемлемым для себя местом после удаления с трона: Михаил Калафат искал в нем убежища, был в нем пострижен и только после ослепления насильно сослан в монастырь Элегмон; Исаак Комнин, после отречения от престола и пострижения в монашество, тоже нашел приют в Студийском монастыре, где пробыл последнее время своей жизни; Михаил Парапинак, вытесненный с престола Вотаниатом, был отправлен после пострижения в Студийский монастырь и только впоследствии, после рукоположения в митрополиты, стал проживать в монастыре Мануила. Вслед за царями и высокопоставленные лица предпочитали Студийский монастырь остальным. Никифор Ксифий, еще при Василии II сосланный на остров Антигона и постриженный в монашество, по возвращении из ссылки при Романе Аргире не пожелал более вмешиваться в государственные дела и принял монашескую схиму в монастыре Студия; Константин Диоген, замешанный в заговоре против Романа, равно и евнух Никифор, спасшийся от погибели во время землетрясения 1035 г., тоже постригся в монахи в Студийском монастыре. Реже, чем Студийский, фигурируют в истории другие из прежде основанных монастырей в столице и в областях, как то: Петрийский, в котором пострижена была и проживала до возведения на престол Феодора, дочь Константина VIII, и куда удалилась Мария, жена Парапинака, с сыном Константином после низвержения мужа с престола; Мануйлов, в который заточен был Романом III Прусиан Болгарин и где проживал Михаил Парапинак, митрополит Ефесский; св. Николая или Моливотон, в котором был погребен император Константин Дука; Мантинийский, где находилась мать Прусиана; Кузина, куда сослан Никифор Протевон; Мирелейский, в котором проживала после пострижения жена Исаака Комнина, Екатерина, с дочерью Марией; Алипос, давший приют больному Мануилу Комнину, в особенности же монастыри на горах: Афоне, Олимпе и Синае» [Скабаланович, 2004, с. 428].

Таким образом, Принцевы острова выступают далеко не единственным местом ссылки или заключения неугодных политиков или людей, опасных для власти, но значительно уступают в этом отношении, например, Студийскому монастырю. С начала XII в. Комнины предпочитают справляться с оппозицией иными способами (в 1105 г. в столице построили башню Анема [Кущ, 2014, с. 82-95]), и Принцевы острова в своем зловещем ореоле постепенно исчезают со страниц источников.

Еще одним важным фактором, оказавшим влияние на судьбу Принцевых островов, является развитие законодательства и пенитенциарной системы в целом. Примечательно, что источники не дают нам практически никаких сведений о наличии в Византии специальных тюрем, предназначенных для заключения и длительного содержания в них политических заключенных ${ }^{35}$, вплоть до возведения в начале XII в. башни Анема, которая начинает использоваться как тюрьма для противников трона.

Важной вехой в развитии византийского законодательства является VIII век, которые исследователи называют «эпохой правового новаторства» [Медведев, 2001, с. 134]. Весьма показательным памятником в этом отношении является Эклога, византийский законодательный свод VIII в. [Липшиц, 1965; Медведев, 1986, с. 221-224; Burgmann, 1983]. Эклога 726 г. представляет собой довольно своеобразный правовой документ, содержащий в себе как традиционные нормы постклассического римского права, так и специфические новые, не характерные для Юстинианова законодательства правовые принципы, возникшие под влиянием христианства [Лысенко, 2014, с. 40-41]. Так, в Эклоге появляются цитаты из Священного писания и меняется само отношение к наказаниям.

Византийское уголовное законодательство, безусловно, унаследовало от Рима весь набор уголовных наказаний, закрепленных в Дигестах и в Кодексе Юстиниана [Кофанов,

${ }^{35}$ Точку зрения о том, что тюремное заключение вплоть до ХІІ в. было мерой предварительной и означало содержание обвиняемого под стражей только до суда, оспаривает, например, Бурдара [Вourdara, 1986, p. 227]. О тюрьмах в Византии см. также: [Bourdara, 1987, p. 111-124; Bourdara, 1997, p. 317-336]. 
2002-2006 ${ }^{36}$, но уже вскоре стало адаптировать их в духе большего ограничения и смягчения или, как сказано в Эклоге, «в духе большего человеколюбия» или «милосердия»

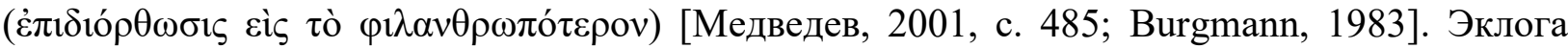
действительно демонстрирует тенденцию к относительному смягчению наказаний, вводя различные увечья и иные меры воздействия вместо смертной казни ${ }^{37}$.

Кроме того, еще одной важной тенденцией, активно проявляющейся начиная c VII-VIII вв., становится влияние христианской политической теории и оформление теории симфонии, что приводит к возможности сочетания одновременно светского и духовного наказания. Государственные преступления в Эклоге стоят в тесной связи с религиозными. Такие тяжкие преступления против государства, как восстание (политический мятеж) и покушение на императора, в значительной мере носили религиозный характер, поскольку византийский император рассматривался как хранитель всего христианского мира и Вселенской Церкви [Лысенко, 2014, с. 37]. Не случайно, согласно ст. 3 титула XVII, подобного преступника надлежало «в тот же час предать смерти как намеревающегося все разрушить». К государственным преступлениям относилась и государственная измена, также карающаяся смертной казнью (титул XVII, ст. 53).

При этом титул XVII Эклоги (Наказания за преступления) дает весьма интересную формулировку: «3. Поднимающего восстание против императора или злоумышляющего, или принимающего участие в заговоре против него или против государства христиан в тот же час должно предать смерти как намеревающегося все разрушить. Но для того чтобы некоторые часто и из вражды не предавали кого-либо смерти без суда, возводя на него обвинение, что он поднимал голос против царства, нужно его взять на месте под хорошую охрану и донести о нем императору, и как сам император в итоге рассудит и решит, так и сделать».

Как справедливо отмечает Е.Э. Липшиц, «данное дополнение, вероятно, ... навеяно эпохой начала VIII в., когда заговоры и смены императоров на византийском престоле стали правилом» [Липшиц, 1965, с. 171]. Однако более любопытно здесь то, что безоговорочное предписание предавать смерти всякого человека, поднимающего восстание против императора или государства, содержащееся в первой части статьи, вступает в противоречие со второй частью статьи, где наказание на месте запрещается во избежание ложных обвинений, а вопрос о характере наказания передается на усмотрение императора. В качестве высшей судебной инстанции в ней фигурирует сам император, решения которого являются безапелляционными. Поскольку церковь не имела собственного карательного аппарата, то император выступал также в роли инстанции, защищающей интересы Церкви методами принуждения [Медведев, 2001, с. 75; Максимович, 2004, с. 181-192].

Примечательно, что речь здесь идет о взятии под стражу как о временной мере, тюремного заключения как формы наказания Эклога не называет [Липшиц, 1965, с. 171-172].

${ }^{36}$ Дигесты предусматривают 4 вида наказаний за серьезные уголовные преступления, по сути, означающие смертную казнь.

${ }^{37}$ Данная тенденция к смягчению уголовных наказаний получит свое продолжение в последующей практике, и знаменитый византийский канонист XII в. Феодор Вальсамон даст ей такое объяснение: «Заметь на основании помещенных в толковании настоящей главы постановлений, что если по Дигестам и Кодексам, имевшим силу до реформы по очищению, под уголовное наказание подводилось и сожжение, $u$ обезглавление, и повешение, то автор очищения царских законов и составитель Василик не принял этого и в изложенных в Василиках постановлениях Кодекса не поместил этих трех наказаний ... Приняв во внимание как многое другое, так равным образом и то, что обезглавление, сожжение, отравление ядом, побиение камнями, низвержение в пропасть есть не уголовное наказание, а бесчеловечное убийство (курсив мой. И.М.), уголовное же наказание - это изгнание, ослепление, отсечение руки и прочее, что дает наказываемому время для раскаяния (в результате) удаления виновного и по причине продолжительности наказания, скажи, что если какие законы из содержащихся в Василиках противны настоящему учению, так это Дигесты, и они не должны иметь силы. Узаконено ведь, что постановления (Василик) предпочтительнее Дигест, когда они узаконивают что-либо относительно одного и того же предмета, и что по законам и всем новеллам мы должны толковать законы в духе большего человеколюбия и сообразно с этим выносить приговоры» [Медведев, 1992, с. 53-61; Медведев, 2001, с. 203]. 
Римские законы (в том числе и Corpus juris Civilis), продолжавшие действовать и в Визанийской империи, предполагают наличие тюрем не столько в качестве наказания за совершенные преступления, сколько в качестве места предварительного заключения на время следствия или как место временного содержания заключенных до приведения приговора в исполнение (Carcer ad continendos homines, non ad puniendos haberi debet. Ulp. Dig. XL VIII. 19, 8). В качестве мест заключения тюрьмы не упоминаются [Olson, 2008, p. 35-36, 46].

В V в. вследствие проникновения христианских норм и идеологии в сферу правового регулирования появляется новая форма наказания - ссылка в монастырь. Первоначально, очевидно, заключение в монастырь применялось по отношению к представителям клира, но уже в 1-й пол. VI в. в своде законов императора Юстиниана такая форма наказания получает юридическое оформление. Правда, пока он применяется в основном в сфере семейного права (в качестве наказания жены за измену мужу). В последующем ссылка в монастырь становится одним из способов решения карьерных проблем. Согласно 48-му Правилу Трулльского собора (692 г.), «жена производимого в епископское достоинство, предварительно разлучася с мужем своим, по общему согласию, по рукоположении его в епископа, да встуnum в монастырь, далеко от обитания сего епископа созданный, и да пользуется содержанием от епископа» (Ап. 5, 51; I Всел. 3; IV Всел. 15; Трул. 12, 14, 30; Карф. 3, 4, 25, 70).

В условиях сложной политической борьбы в период иконоборчества монастырская ссылка быстро становится относительно гуманным и надежным способом «решения проблем» - политических, аппаратных и карьерных. Помимо государственных преступников, уличенных в государственной измене, участии в заговорах или переворотах, серьезную опасность, хотя и потенциальную, составляли представители царского рода, могущие претендовать на власть, представители оппозиции (светской и духовной), не согласные и открыто критикующие императорскую политику. Особенно актуальной эта проблема становится в VIII-IX вв. Не совершив никакого преступления, такие люди тем не менее представляли опасность для правящего императора. В условиях, когда казнь была невозможна, но необходимо было устранить политического противника, ссылка и заключение в монастырь становятся идеальным решением проблемы. Изменение законодательства создает необходимые предпосылки для такого развития событий. Интересно, что заключение в монастырь, применяемое Юстиниановым правом (Nov. Just. 134. 10, I [556]) [Blume, 2020] и позднейшим правом, как одна из форм наказания в Эклоге не упоминается. Е.Э. Липшиц объясняет данное обстоятельство антимонастырской направленностью политики иконоборческих императоров [Липшиц, 1965, с. 172], хотя на практике императоры-иконоборцы весьма активно использовали этот метод устранения политических противников. Именно с начала VIII в. в практику наказаний все активнее вводится монастырское заключение. На наш взгляд, удаление политического противника в монастырь пока еще носит добровольно-принудительный характер и служит, вероятно, не столько для удержания под стражей, ограничения деятельности или причинения какого-либо ущерба, сколько для смирения гордыни и искупления грехов. Особый смысл данная мера имела для представителей царствующего дома. Добровольный или насильственный уход в монастырь означал устранение от политической жизни нежелательных соперников при сохранении жизни представителям императорской фамилии.

Кроме того, ссылка высокопоставленных особ и заключение их в монастырь, вероятно, не предполагали выделения специальных средств из казны на их содержание (редкие случаи выделения такого жалования особо отмечаются в источниках), и таким образом обязанность их содержать возлагалась на монастырь.

Итак, изменение внутри- и внешнеполитической ситуации в VIII-IX вв. в сочетании с развитием законодательства и судебной системы приводят к тому, что довольно распространенной практикой наказания, а вернее, способом предотвращения потенциальной угрозы становится ссылка высокопоставленных противников на Принцевы острова и монастырское заключение. Это был идеальный способ сохранить жизнь высокородным политическим соперникам и прямым оппонентам и в то же время устранить их надолго от 
участия в политической жизни. Пик расцвета Принцевых островов не случайно приходится на эпоху иконоборчества (711-843 гг.) и следующие за ней столетия - время активной политической борьбы и развития монастырского строительства. C VIII в. государство активно использует монастыри в качестве пенитенциарных учреждений. Принцевы острова в этом отношении как нельзя лучше подходили в качестве места (добровольного или принудительного) уединения, трудов и молитвенных занятий. Позднее, с XII в., Комнины начинают использовать новые формы борьбы с оппозицией, строят гражданскую тюрьму Анемас (в которой было специально приготовлено 2 этажа по 14 камер для политических заключенных), а после появления здесь крестоносцев Принцевы острова постепенно приходят в запустение и становятся практически безлюдными.

\section{Список литературы}

1. Азаревич Д. 1877. История византийского права. Ярославль [Б. и.]. Ч. 2, 352.

2. Васильев А.А. 1998а. История Византийской империи. Т. 1. СПб., Алетейя, 510.

3. Васильев А.А. 1998b. История Византийской империи. Т. 2. СПб., Алетейя, 593.

4. Васильевский В.Г. 1899. В защиту подлинности жития патриарха Игнатия и принадлежности его современному автору, Никите Пафлагону. Византийский Временник. Т. VI, вып. 1-2: 39-56.

5. Гроссу Н. 1907. Преп. Феодор Студит. Его время, жизнь и творения. 2 т. Киев, тип. Просвещение, 312.

6. Дашков С.Б. 1997. Императоры Византии. М., Красная площадь, 558.

7. Диль Ш. 1994. Византийские портреты. Пер. с фр. М. Безобразовой. М., Искусство, 447.

8. Доброклонский А.П. 1913. Преп. Феодор, исповедник и игумен Студийский. Ч. 1: Его эпоха, жизнь и деятельность. Записки Императорского Новороссийского университета. Т. 113, 1098.

9. Доброклонский А.П. 1914. Преп. Феодор, исповедник и игумен Студийский. Ч. 2: Его творения. Записки Императорского Новороссийского университета. Ист.-филол. фак. Одесса. Вып. 8, 570.

10. Долоцкий В.И. (изд.). 1860-1862. Никиты Хониата История, начинающаяся с царствования Иоанна Комнина. В 2 т. Т. 1. СПб., С.-Петербургская Духовная Академия, 564.

11. Иванов С.А. 2013. В поисках Константинополя. Путеводитель по византийскому Стамбулу и окрестностям. М., Вокруг света, 688.

12. Коркмас Д., Скоковская М. 1919. Иллюстрированный путеводитель по Константинополю, окрестностям и провинции. Константинополь, Бабок, 426.

13. Кофанов Л.Л. (изд.). 2002-2006. Дигесты Юстиниана: В 8 т. М., Статут.

14. Кущ Т.В. 2014. Узники башни Анема. Вопросы истории. 11: 82-95.

15. Липшиц Е.Э. (изд.). 1950. Никифора патриарха Константинопольского краткая история со времени после царствования Маврикия. Византийский временник. Т. 3 (28): 349-387.

16. Липшиц Е.Э. (изд.). 1965. Эклога: Византийский законодательный свод VIII века. М., Наука, 226.

17. Липшиц Е.Э. 1976. Право и суд в Византии в IV-VIII вв. Л., Наука, 230.

18. Липшиц Е.Э. 1981. Законодательство и юриспруденция в Византии в IX-XI вв. Л., Наука, 246.

19. Лысенко О.Л. 2014. Эклога 726 г. Памятник права Византии эпохи иконоборчества и «правового новаторства». Вестник Московского университета. Серия 11. Право. 3: 16-41.

20. Любарский Я.Н. (изд.). 2009. Продолжатель Феофана. Жизнеописание византийских царей. СПб., Алетейя: 400.

21. Любарский Я.Н. и др. (изд.). 2003. Михаил Пселл. Хронография. Краткая история. СПб., Алетейя: 396.

22. Максимович К.А. 2004. Право и церковь (Византийская империя). Православная энциклопедия. М., ЦНЦ «Православная энциклопедия». Т. 8: 181-192.

23. Медведев И.П. 1986. Рецензия на: Ecloga: Das Gesetzbuch Leons III. und Konstantinos V. Hrsg. von L. Burgmann (Forschungen zur byzantinischen Rechtsgeschichte / Hrsg. von D. Simon, Bd. 10). Frankfurt am Main, 1983. Византийский Временник. Т. 46 (71): 221-224. 
24. Медведев И.П. 1992. Смертная казнь в толковании Феодора Вальсамона. Византийский Временник. Т. 53 (78): 53-61.

25. Медведев И.П. 2001. Правовая культура Византийской империи. СПб., Алетейя, 575.

26. Митр. Ташкентский и Среднеазиатский Владимир (изд.). 2011. Преп. Феодор Студит. Слово Х. Преподобного отца нашего и исповедника Феодора, игумена Студийского, надгробное слово в честь Платона, его духовного отца. Преп. Феодор Студит. Творения. В 3 т. Т. 2. Нравственно-аскетические творения. Догматико-полемические творения. Слова. Литургикоканонические творения. (Полное собрание творений святых отцов Церкви и церковных писателей в русском переводе. Т. 6). М., Сибирская благозвонница, 864.

27. Оболенский В.И. и др. (изд.) 1884. Летопись византийца Феофана от Диоклетиана до царей Михаила и сына его Феофилакта. М., Ун-т типогр. на Страстн. б-ре М. Каткова, 606.

28. Попов Д. (изд.). 1820. История Льва Диакона Калойского и другие сочинения византийских писателей, изданные в первый раз с рукописей Корол. Парижской Библиотеки и объясненные примечаниями Карлом Бенедиктом Газе. Пер. с греческого. СПб., 332.

29. Преображенский В. 1896. Преподобный Феодор Студит и его время (759-826 гг.). М., Типо-литогр. Ермакова, 356.

30. Св. Димитрий Ростовский. 2004. Житие и страдание святого преподобномученика и исповедника Феодора и брата его преподобного Феофана начертанных. Жития святых на русском языке, изложенные по руководству Четьих-Миней св. Димитрия Ростовского. В 12 кн. T. IV. Meсяц декабрь. 27 декабря. Киев, Свято-Успенская Киево-Печерская Лавра: 764-784.

31. Скабаланович Н.А. 2004. Византийское государство и церковь в ХІ в.: От смерти Василия II Болгаробойцы до воцарения Алексея I Комнина. СПб., Издательство Олега Абышко, 864.

32. Соколов И.И. 1894a. Состояние монашества в византийской церкви с половины IX до начала ХІІІ в. (842-1204): Опыт церк.-ист. исслед. Казань, типо-лит. Имп. ун-та, 536.

33. Соколов И.И. 1894b. О византийско-восточном монашестве IX-XII вв. Православный собеседник. Июль: 1-24.

34. Соколов И.И. 2003. Состояние монашества в Византийской Церкви с середины IX до начала XIII века (842-1204). СПб., Изд-во Олега Абышко, 464.

35. Соколов И.И. 2005. Преподобный Феодор Студит, его церковно-общественная и богословско-литературная деятельность. Соколов И.И. Лекции по истории Греко-Восточной Церкви: В 2 т. Т. 2. СПб., Издательство Олега Абышко: 209-321.

36. Суворов Н.С. 1876. О церковных наказаниях. Опыт исследования по церковному праву. СПб., типография А. Траншеля, 346.

37. Успенский Ф.И. 2005. История Византийской империи. В 5 т. Т. 2. М., АСТ; Астрель, 558.

38. Филиппов С.Н. 1915. Константинополь, его окрестности и Принцевы острова. Пг., В. Березовский, 279.

39. Фойницкий И.Я. 1889. Учение о наказаниях в связи с тюрьмоведением. СПб., тип. М-ва пут. сообщ. (А. Бенке), 514.

40. Чичуров И.С. 1980. Византийские исторические сочинения «Хронография» Феофана, «Бревиарий» Никифора. Тексты, перевод, комментарий. М., Наука, 216.

41. Afinogenov D. 2010. The Story of the Patriarch Constantine II of Constantinople in Theophanes and George the Monk: Transformations of a Narrative. In: History as Literature in Byzantium: Papers. Ed. R. Macrides. Farnham: 207-214.

42. Allen P. 1980. Neo-Chalcedonism and the Patriarchs of the Late 6th Century. In: Byzantion. Vol. 50: 5-17.

43. Beck H-G. 1979. Geschichte der orthodoxen Kirche im byzantinischen Reich. Goettingen, Vandenhoeck \& Ruprecht, 268.

44. Blume F.H. (ed.). 2020. Justinian's Novels. In: George W. Hopper Law Library. URL: http://www.uwyo.edu/lawlib/index.html (дата обращения 15.04.2020 [acsessed 15 April 2020]).

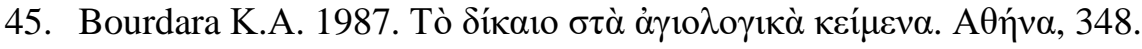

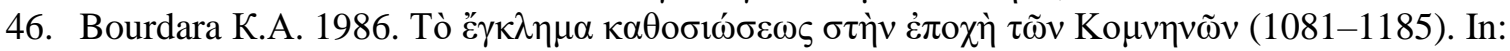
A

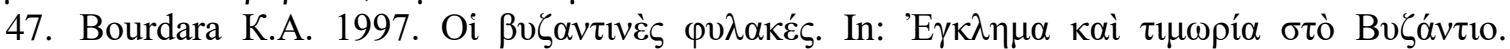
A $\theta \dot{v} v \alpha: 317-336$.

48. Burgmann L. (ed.). 1983. Eclogä Das Gesetzbuch Leons III. und Konstantinos V. Frankfurt a/M., 543. 
49. Cameron A. 1988. Eustratios' Life of the Patriarch Eutychius and the Fifth Oecumenical Council. In: Kathegetria: Essays presented to J. Hussey for her 80th birthday. Camberley: 225-247.

50. Chitwood Z. 2017. Byzantine Legal Culture and the Roman Legal Tradition, 867-1056. Cambridge, Cambridge University Press, 235.

51. Dagron G. 1994. Lawful Society and Legitimate Power. In: Law and Society in Byzantium: Ninth-Twelth Centuries. Washington: 27-51.

52. Freely J. 2007. The Prince's Islands. Istanbul, Adali Yayinlari, 120.

53. Gautier P. (ed.). 1986. Theophylacte d'Achrida. Letters. Thessalonica, 4: 3-99.

54. Hillner J. 2007. Monastic Imprisonment in Justinian's Novels. In: Journal of Early Christian Studies. 15/2: 205-237.

55. Hillner J. 2011. Enfermement monastique au VIe siècle. In: J. Claustre, I. Heullant-Donant (eds.), Enfermements: Le cloître et la prison du Ve au XVIIIe siècle. Paris, Publications de la Sorbonne: $39-56$

56. Hillner J. 2013. Confined Exiles: An Aspect of the Late Antique Prison System. In: Millennium. Jahrbuch zur Kultur und Geschichte des ersten Jahrtausend n. Chr. 10 (1): 385-433.

57. Hillner J. 2015. Prison, Punishment and Penance in Late Antiquity. Cambridge, Cambridge University Press, 422.

58. Humphreys M.T.G. 2015. Law, Power and Imperial Ideology in the Iconoclast Era, c. 680-850. Oxford, Oxford University Press, 336.

59. Hussey J. (ed.). 1967. The Cambridge Medieval History. Vol. IV: The Byzantine Empire Part II: Government, Church and Civilization. Cambridge, Cambridge University Press, 517.

60. Kazhdan A.P. (ed.). 2005. Prince's Islands. In: Oxford Dictionary of Byzantium. Oxford, Oxford University Press: 1720.

61. Laga C. (ed.). 1992. Eustratii Presbyteri Vita Eutychii Patriarchae Constantinopolitani. Corpus Christianorum. Series Graeca. Vol. 25. Turnhout; Leuven, 104.

62. Lawler J. 2004. Encyclopedia of the Byzantine Empire. Mcfahrland, 376.

63. Lepree J.F., Djukic L. (eds.). 2019. The Byzantine Empire: A Historical Encyclopedia. Vol 1-2. ABC-Clio, 626.

64. Mathews Th., Mango C. 1973. Observations on the Church of Panagia Kamariotissa on Heybeliada (Chalke), Istanbul with a Note on Panagia Kamariotissa and Some Imperial Foundations of the Tenth and Eleventh Centuries at Constantinople In: DOP. Vol. 27: 115-132.

65. Migne J.-P. 1857. Theodorus Studita Oratio Funeralis In Platon. In: S.P.N. Theodori Studitae. Opera Omnia. Patrologia Graeca. T. 99. Col. 803-849.

66. Migne J.-P. 1862. Nicetas David Paphlago. Vita S. Ignatii atchiepiscopi Constantinopolitani. In: Nicetae Paphlagonis, qui et David, Nicetae Byzantini. Opera quae, reperiri potuerunt omnia. Patrologia Graeca. T. 105. Col. 487-575.

67. Morris N., Rothman D.J. (eds.). 1998. The Oxford History of the Prison: The Practice of Punishment in Western Society, New York, Oxford University Press, 489.

68. Olson M. 2008. Philosophies of Imprisonment in Late Antiquity. In: Constructing the Past: Vol. 9: Iss. 1, Article 7: 29-46.

69. Pargone J. 1902. Les Monasteres de S.-Ignace et les cinq plus petits ilots de l'archipel des Princes. In: Bibliotheca Chersonessitana: ИРАИК. Т. 7: 56-91.

70. Pokock R. 1745. Observations on the Islands of the Archipelago, Asia Minor, Thrace, Greece. London, Bowyer, 458.

71. Sartorius I. 2011. The Princes' Islands: Istanbul's Archipelago. London, T.H.E. Armchair Traveller AT T.H.E. Bookhaus, 120.

72. Smithies A. 1988. Nicetas Paphlago's Life of Ignatius: A critical edition with translation, PhD Diss., State University of New York at Buffalo, 193.

73. Stolte B. 2018. Byzantine Law: The Law of the New Rome. In: The Oxford Handbook of European Legal History. Eds. H. Pihlajamäki, M.D. Dubber, M. Godfrey. Oxford, Oxford University Press: 229-248.

74. Stratos A. 1980. Byzantium in the Seventh Century: Justinian II, Leontius and Tiberius, 685-711. Amsterdam, Adolf M. Hakker, 203.

75. Thomas J., Hero A.C. (eds.). 2000. Byzantine monastic foundation documents. A complete translation of the surviving founders' Typika and testaments. In 5 vols. Vol.5. Dumbarton Oaks Studies, 35. Washington, Dumbarton Oaks Research Library and Collection, 342. 
76. Whitbey M. 1987. Eutychius, Patriarch of Constantinople: An Epic Holy Man. In: Homo Viator: Classical Essays for J. Bramble. Ed. M. Whitbey, P. Hardie, M. Whitbey. Bristol, Bristol University Press: 297-308.

\section{References}

1. Azarevich D. 1877. Istoriia vizantiiskogo prava [History of Byzantine law]. Yaroslavl' [B. i.]. Ch. 2, 352 (in Russian).

2. Vasil'ev A.A. 1998a. Istoriya Vizantijskoj imperii [History of Byzantine Empire]. T. 1. Saint Petersburg, Aletejya, 510 (in Russian).

3. Vasil'ev A.A. 1998b. Istoriya Vizantijskoj imperii [History of Byzantine Empire]. T. 2. Saint Petersburg, Aletejya, 593 (in Russian).

4. Vasil'evskij V.G. 1899. V zashchitu podlinnosti zhitiya patriarha Ignatiya i prinadlezhnosti ego sovremennomu avtoru, Nikite Paflagonu [In defense of the authenticity of the life of Patriarch Ignatius and belonging to its modern author, Nikita Paflagon]. In: Vizantijskij Vremennik. T. VI, vyp. 1-2: 39-56 (in Russian).

5. Grossu N. 1907. Prep. Feodor Studit. Ego vremya, zhizn' i tvoreniya [Rev. Theodore Studite. His time, life and creations]. 2 T. Kiev, tip. Prosveshchenie, 312 (in Russian).

6. Dashkov S.B. 1997. Imperatory Vizantii [Emperors of Byzantium]. Moscow, Krasnaya ploshchad', 558 (in Russian).

7. Dil' Sh. 1994. Vizantijskie portrety [Byzantine portraits]. Per. s fr. M. Bezobrazovoj. Moscow, Iskusstvo, 447 (in Russian).

8. Dobroklonskij A.P. 1913. Prep. Feodor, ispovednik i igumen studijskij. Ch. 1: Ego epoha, zhizn' i deyatel'nost' [Prep. Theodore, confessor and abbot studio. Part 1: His era, life and work]. In: Zapiski Imperatorskogo Novorossijskogo universiteta. T. 113: 1098 (in Russian).

9. Dobroklonskij A.P. 1914. Prep. Feodor, ispovednik i igumen studijskij. Ch. 2: Ego tvoreniya [Rev. Theodore, confessor and abbot studio. 2: His creations.]. In: Zapiski Imperatorskogo Novorossijskogo universiteta. Ist.-filol. fak. Odessa. Vyp. 8: 570 (in Russian).

10. Dolockij V.I. (izd.). 1860-1862. Nikity Honiata Istoriya, nachinayushchayasya s carstvovaniya Ioanna Komnina [Nikita Choniate. The story starting with the reign of John Komnin]. V 2 t. T. 1. Saint Petersburg, S.-Peterburgskaya Duhovnaya Akademiya, 564 (in Russian).

11. Ivanov S.A. 2013. V poiskah Konstantinopolya. Putevoditel' po vizantijskomu Stambulu i okrestnostyam [In search of Constantinople. Guide to Byzantine Istanbul and the surrounding area]. Moscow, Vokrug sveta, 688 (in Russian).

12. Korkmas D., Skokovskaya M. 1919. Illyustrirovannyj putevoditel' po Konstantinopolyu, okrestnostyam i provincii [Illustrated guide to Constantinople, the surrounding area and the province]. Konstantinopol', Babok, 426 (in Russian).

13. Kofanov L.L. (izd.). 2002-2006. Digesty Yustiniana [Justinian Digest]: V 8 t. Moscow, Statut (in Russian).

14. Kushch T.V. 2014. Uzniki bashni Anema [Prisoners of the tower of Anem]. In: Voprosy istorii. 11: 82-95 (in Russian).

15. Lipshic E.E. (izd.). 1950. Nikifora patriarha Konstantinopol'skogo kratkaya istoriya so vremeni posle carstvovaniya Mavrikiya [Nicephorus patriarch of Constantinople a brief history from the time after the reign of Mauritius]. In: Vizantijskij vremennik. T. 3 (28): 349-387 (in Russian).

16. Lipshic E.E. (izd.). 1965. Ekloga: Vizantijskij zakonodatel'nyj svod VIII veka [Ekloga: Vizantijskij zakonodatel'nyj svod VIII veka]. Moscow, Nauka, 226 (iIn Russian).

17. Lipshic E.E. 1976. Pravo i sud v Vizantii v IV-VIII vv. [Law and court in Byzantium in the IV-VIIII centuries]. Leningrad, Nauka, 230 (in Russian).

18. Lipshic E.E. 1981. Zakonodatel'stvo i yurisprudenciya v Vizantii v IX-XI vv. [Legislation and jurisprudence in Byzantium in the $9^{\text {th }}-11^{\text {th }}$ centuries]. Leningrad, Nauka, 246 (in Russian).

19. Lysenko O.L. 2014. Ekloga 726 g. Pamyatnik prava Vizantii epohi ikonoborchestva i «pravovogo novatorstva» [Eclogue 726. Monument to Byzantine law of the era of iconoclasm and «legal innovation»]. In: Vestnik Moskovskogo universiteta. Seriya 11. Pravo. 3: 16-41 (in Russian).

20. Lyubarskij Ya.N. (izd.). 2009. Prodolzhatel' Feofana. Zhizneopisanie vizantijskih carej [The successor of Theophanes. Biography of the Byzantine kings]. Saint Petersburg, Aletejya, 400 (in Russian). 
21. Lyubarskij Ya.N. i dr. (izd.). 2003. Mihail Psell. Hronografiya. Kratkaya istoriya [Michael Psell. Chronography Short story]. Saint Petersburg, Aletejya, 396 (in Russian).

22. Maksimovich K.A. 2004. Pravo i cerkov' (Vizantijskaya imperiya) [Law and Church (Byzantine Empire)]. In: Pravoslavnaya enciklopediya. M., CNC «Pravoslavnaya enciklopediya». T. 8: 181-192. (in Russian)

23. Medvedev I.P. 1986. Recenziya na: Ecloga: Das Gesetzbuch Leons III. und Konstantinos V. Hrsg. von L. Burgmann (Forschungen zur byzantinischen Rechtsgeschichte. Hrsg. von D. Simon, Bd. 10). Frankfurt am Main, 1983 [Review of: Ecloga: Das Gesetzbuch Leons III. und Konstantinos V. Hrsg. von L. Burgmann (Forschungen zur byzantinischen Rechtsgeschichte. Hrsg. von D. Simon, Bd. 10). Frankfurt am Main, 1983]. In: Vizantijskij Vremennik. T. 46 (71): 221-224 (in Russian).

24. Medvedev I.P. 1992. Smertnaya kazn' v tolkovanii Feodora Val'samona [The death penalty in the interpretation of Theodore Walsamon]. In: Vizantijskij vremennik . T. 53 (78): 53-61 (in Russian).

25. Medvedev I.P. 2001. Pravovaya kul'tura Vizantijskoj imperii [Legal Culture of the Byzantine Empire]. Saint Petersburg, Aletejya, 575 (in Russian).

26. Mitr. Tashkentskij i Sredneaziatskij Vladimir (izd.). 2011. Prep. Feodor Studit. Slovo X. Prepodobnogo otca nashego i ispovednika Feodora, igumena Studijskogo, nadgrobnoe slovo v chest' Platona, ego duhovnogo otca [Rev. Theodore Studite. The word X. Our Monk Father and Confessor Theodore, Father Superior of Studios, gravestone in honor of Plato, his spiritual father]. In: Prep. Feodor Studit. Tvoreniya. V 3 t. T. 2. Nravstvenno-asketicheskie tvoreniya. Dogmatiko-polemicheskie tvoreniya. Slova. Liturgiko-kanonicheskie tvoreniya (Polnoe sobranie tvorenij svyatyh otcov Cerkvi i cerkovnyh pisatelej v russkom perevode. T. 6) [Rev. Theodore Studite. Creations. In 3 vols. T. 2. Moral and ascetic creations. Dogmatic polemical creations. The words. Liturgical-canonical creations (The complete collection of creations of the Holy Fathers of the Church and church writers in the Russian translation. V.6)]. Moscow, Sibirskaya blagozvonnica, 864 (in Russian).

27. Obolenskij V.I. i dr. (izd.) 1884. Letopis' vizantijca Feofana ot Diokletiana do carej Mihaila i syna ego Feofilakta [Chronicle of the Byzantine Theophanes from Diocletian to the kings of Michael and his son Theophylact]. Moscow, Un-t tipogr. na Strastn. b-re M. Katkova, 606 (in Russian).

28. Popov D. (izd.). 1820. Istoriya L'va Diakona Kalojskogo i drugie sochineniya vizantijskih pisatelej, izdannye v pervyj raz s rukopisej Korol. Parizhskoj Biblioteki i ob"yasnennye primechaniyami Karlom Benediktom Gaze. Per. s grecheskogo [The story of Leo Deacon Kaloysky and other works of Byzantine writers, published for the first time from the King's manuscripts. Paris Library and explained by notes by Carl Benedict Gaza. Trans. from Greek]. Saint Petersburg, 322 (in Russian).

29. Preobrazhenskij V. 1896. Prepodobnyj Feodor Studit i ego vremya (759-826 gg.) [Rev. Theodore Studite and his time (759-826)]. Moscow, Tipo-litogr. Ermakova, 356 (in Russian).

30. Sv. Dimitrij Rostovskij. 2004. Zhitie i stradanie svyatogo prepodobnomuchenika i ispovednika Feodora i brata ego prepodobnogo Feofana nachertannyh [The Life and Suffering of the Holy Rev. Martyr and Confessor Theodore and his brother Rev. Theophanes inscribed]. In: Zhitiya svyatyh na russkom yazyke, izlozhennye po rukovodstvu Chet'ih-Minej sv. Dimitriya Rostovskogo. V $12 \mathrm{kn}$. T. IV. Mesyac dekabr'. 27 dekabrya [The lives of the saints in Russian, set out according to the guidance of Chetyih-Miney sv. Demetrius of Rostov. In $12 \mathrm{kn}$. T. IV. The month of December. 27th of December]. Kiev, Svyato-Uspenskaya Kievo-Pecherskaya Lavra: 764-784 (in Russian).

31. Skabalanovich N.A. 2004. Vizantijskoe gosudarstvo i cerkov' v XI v.: Ot smerti Vasiliya II Bolgarobojcy do vocareniya Alekseya I Komnina [The Byzantine state and the church in the XI century.: From the death of Basil II the Bulgarian Slayer to the accession of Alexei I Komnin]. Saint Petersburg, Izdatel'stvo Olega Abyshko, 864 (in Russian).

32. Sokolov I.I. 1894a. Sostoyanie monashestva v vizantijskoj cerkvi s poloviny IX do nachala XIII v. (842-1204): Opyt cerk.-ist. issled [The state of monasticism in the Byzantine church from half IX to the beginning of the XIII century (842-1204): The experience of the church.-hist. research] Kazan', tipo-lit. Imp. un-ta, 536 (in Russian).

33. Sokolov I.I. 1894b. O vizantijsko-vostochnom monashestve IX-XII vv. [On ByzantineEastern monasticism of the $9^{\text {th }}-12^{\text {th }}$ centuries]. Pravoslavnyj sobesednik. Iyul': 1-24 (in Russian).

34. Sokolov I.I. 2003. Sostoyanie monashestva v Vizantijskoj Cerkvi s serediny IX do nachala XIII veka (842-1204) [The state of monasticism in the Byzantine church from half IX to the beginning of the XIII century (842-1204)]. Saint Petersburg, Izd-vo Olega Abyshko, 464 (in Russian).

35. Sokolov I.I. 2005. Prepodobnyj Feodor Studit, ego cerkovno-obshchestvennaya i bogoslovsko-literaturnaya deyatel'nost' [Rev. Theodore Studite, his church-public and theological and liter- 
ary activity]. In: Sokolov I.I. Lekcii po istorii Greko-Vostochnoj Cerkvi [Lectures on the history of the Greek East Church]: V 2 t. T. 2. Saint Petersburg: Izdatel'stvo Olega Abyshko: 209-321 (in Russian).

36. Suvorov N.S. 1876. O cerkovnyh nakazaniyah. Opyt issledovaniya po cerkovnomu pravu [About church punishments. Research experience in church law]. Saint Petersburg, Tipografiya A. Transhelya, 346 (in Russian).

37. Uspenskij F.I. 2005. Istoriya Vizantijskoj imperii [History of the Byzantine Empire]. V 5 t. T. 2. Moscow, AST; Astrel', 558 (in Russian).

38. Filippov S.N. 1915. Konstantinopol', ego okrestnosti i Princevy ostrova [Constantinople, its environs and the Princes' Islands]. Praga, V. Berezovskij, 279 (in Russian).

39. Fojnickij I.Ya. 1889. Uchenie o nakazaniyah v svyazi s tyur'movedeniem [The doctrine of penalties in relation to prison science]. Saint Petersburg, Tip. M-va put. soobshch. (A. Benke), 514 (in Russian).

40. Chichurov I.S. 1980. Vizantijskie istoricheskie sochineniya «Hronografiya» Feofana, «Breviarij» Nikifora. Teksty, perevod, kommentarij [The Byzantine historical works «Chronography» of Theophanes, «Breviary» of Nicephorus. Texts, translation, commentary]. Moscow, Nauka, 216 (in Russian).

41. Afinogenov D. 2010. The Story of the Patriarch Constantine II of Constantinople in Theophanes and George the Monk: Transformations of a Narrative. In: History as Literature in Byzantium: Papers. Ed. R. Macrides. Farnham: 207-214.

42. Allen P. 1980. Neo-Chalcedonism and the Patriarchs of the Late 6th Century. In: Byzantion. Vol. 50: 5-17.

43. Beck H-G. 1979. Geschichte der orthodoxen Kirche im byzantinischen Reich. Goettingen, Vandenhoeck \& Ruprecht, 268.

44. Blume F.H. (ed.). 2020. Justinian's Novels. In: George W. Hopper Law Library. URL: http://www.uwyo.edu/lawlib/index.html (дата обращения 15.04.2020 [acsessed 15 April 2020]).

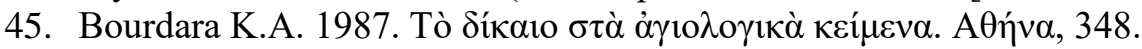

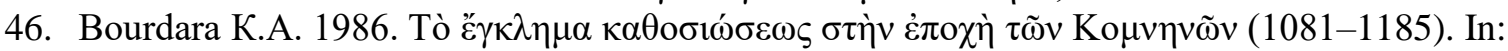

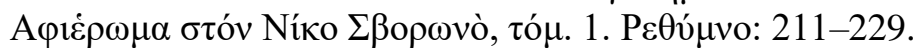

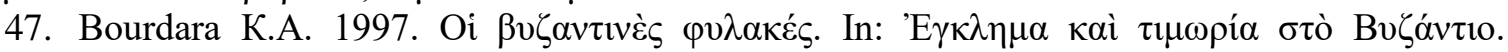
A $\theta \dot{v} v \alpha: 317-336$. a/M., 543.

48. Burgmann L. (ed.). 1983. Eclogä Das Gesetzbuch Leons III. und Konstantinos V. Frankfurt

49. Cameron A. 1988. Eustratios' Life of the Patriarch Eutychius and the Fifth Oecumenical Council. In: Kathegetria: Essays presented to J. Hussey for her 80th birthday. Camberley: 225-247.

50. Chitwood Z. 2017. Byzantine Legal Culture and the Roman Legal Tradition, 867-1056. Cambridge, Cambridge University Press, 235.

51. Dagron G. 1994. Lawful Society and Legitimate Power. In: Law and Society in Byzantium: Ninth-Twelth Centuries. Washington: 27-51.

52. Freely J. 2007. The Prince's Islands. Istanbul, Adali Yayinlari, 120.

53. Gautier P. (ed.). 1986. Theophylacte d'Achrida. Letters. Thessalonica, 4: 3-99.

54. Hillner J. 2007. Monastic Imprisonment in Justinian's Novels. In: Journal of Early Christian Studies. 15/2: 205-237.

55. Hillner J. 2011. Enfermement monastique au VIe siècle. In: J. Claustre, I. Heullant-Donant (eds.), Enfermements: Le cloître et la prison du Ve au XVIIIe siècle. Paris, Publications de la Sorbonne: $39-56$.

56. Hillner J. 2013. Confined Exiles: An Aspect of the Late Antique Prison System. In: Millennium. Jahrbuch zur Kultur und Geschichte des ersten Jahrtausend n. Chr. 10 (1): 385-433.

57. Hillner J. 2015. Prison, Punishment and Penance in Late Antiquity. Cambridge, Cambridge University Press, 422.

58. Humphreys M.T.G. 2015. Law, Power and Imperial Ideology in the Iconoclast Era, c. 680-850. Oxford, Oxford University Press, 336.

59. Hussey J. (ed.). 1967. The Cambridge Medieval History. Vol. IV: The Byzantine Empire Part II: Government, Church and Civilization. Cambridge, Cambridge University Press, 517.

60. Kazhdan A.P. (ed.). 2005. Prince's Islands. In: Oxford Dictionary of Byzantium. Oxford, Oxford University Press: 1720.

61. Laga C. (ed.). 1992. Eustratii Presbyteri Vita Eutychii Patriarchae Constantinopolitani. Corpus Christianorum. Series Graeca. Vol. 25. Turnhout; Leuven, 104. 
62. Lawler J. 2004. Encyclopedia of the Byzantine Empire. Mcfahrland, 376.

63. Lepree J.F., Djukic L. (eds.). 2019. The Byzantine Empire: A Historical Encyclopedia. Vol 1-2. ABC-Clio, 626.

64. Mathews Th., Mango C. 1973. Observations on the Church of Panagia Kamariotissa on Heybeliada (Chalke), Istanbul with a Note on Panagia Kamariotissa and Some Imperial Foundations of the Tenth and Eleventh Centuries at Constantinople In: DOP. Vol. 27: 115-132.

65. Migne J.-P. 1857. Theodorus Studita Oratio Funeralis In Platon. In: S.P.N. Theodori Studitae. Opera Omnia. Patrologia Graeca. T. 99. Col. 803-849.

66. Migne J.-P. 1862. Nicetas David Paphlago. Vita S. Ignatii atchiepiscopi Constantinopolitani. In: Nicetae Paphlagonis, qui et David, Nicetae Byzantini. Opera quae, reperiri potuerunt omnia. Patrologia Graeca. T. 105. Col. 487-575.

67. Morris N., Rothman D.J. (eds.). 1998. The Oxford History of the Prison: The Practice of Punishment in Western Society, New York, Oxford University Press, 489.

68. Olson M. 2008. Philosophies of Imprisonment in Late Antiquity. In: Constructing the Past: Vol. 9: Iss. 1, Article 7: 29-46.

69. Pargone J. 1902. Les Monasteres de S.-Ignace et les cinq plus petits ilots de l'archipel des Princes. In: Bibliotheca Chersonessitana: ИРАИК. Т. 7: 56-91.

70. Pokock R. 1745. Observations on the Islands of the Archipelago, Asia Minor, Thrace, Greece. London, Bowyer, 458.

71. Sartorius I. 2011. The Princes' Islands: Istanbul's Archipelago. London, T.H.E. Armchair Traveller AT T.H.E. Bookhaus, 120.

72. Smithies A. 1988. Nicetas Paphlago's Life of Ignatius: A critical edition with translation, PhD Diss., State University of New York at Buffalo, 193.

73. Stolte B. 2018. Byzantine Law: The Law of the New Rome. In: The Oxford Handbook of European Legal History. Eds. H. Pihlajamäki, M.D. Dubber, M. Godfrey. Oxford, Oxford University Press: 229-248.

74. Stratos A. 1980. Byzantium in the Seventh Century: Justinian II, Leontius and Tiberius, 685-711. Amsterdam, Adolf M. Hakker, 203.

75. Thomas J., Hero A.C. (eds.). 2000. Byzantine monastic foundation documents. A complete translation of the surviving founders' Typika and testaments. In 5 vols. Vol.5. Dumbarton Oaks Studies, 35. Washington, Dumbarton Oaks Research Library and Collection, 342.

76. Whitbey M. 1987. Eutychius, Patriarch of Constantinople: An Epic Holy Man. In: Homo Viator: Classical Essays for J. Bramble. Ed. M. Whitbey, P. Hardie, M. Whitbey. Bristol, Bristol University Press: 297-308.

\section{ИНФОРМАЦИЯ ОБ АВТОРЕ}

\begin{tabular}{lrr} 
Ващева Ирина & \multicolumn{1}{c}{ Юрьевна, } \\
исторических ноктор & паук, профессор кафедры \\
истории средневековых & цивилизаций \\
Национального & исследовательского \\
Нижегородского & государственного \\
университета им. Н.И. Лобачевского, г. Нижний \\
Новгород, Россия
\end{tabular}

\section{INFORMATION ABOUT THE AUTHOR}

Irina Yu. Vascheva, Doctor of Historical Sciences, Professor of the Department of the History of Medieval Civilizations of the National Research Nizhny Novgorod State University named after N.I. Lobachevsky, Nizhny Novgorod, Russia 